\title{
Survey of medical care by oncologists for depression in breast cancer patients
}

\author{
Izumi Sato $^{1,2)}$, Haruhiko Makino ${ }^{2,3)}$, \\ Kojiro Shimozuma ${ }^{2,4)}$ and Yasuo Ohashi ${ }^{1,2)}$
}

1) Department of Biostatistics/Epidemiology and Preventive Health Sciences, The University of Tokyo

2) Public Health Research Foundation

3) Division of Breast Oncology, Niigata City General Hospital

4) Department of Biomedical Sciences, College of Life Sciences, Ritsumeikan University

Recived 3/18/2014, revised 4/28/2014, accepted 5/15/2014

\begin{abstract}
Objective: To investigate the perception of the prevalence of mental diseases in breast cancer patients and the therapeutic approach to depression undertaken by oncologists. Method: Self-reported questionnaires were sent to 352 breast cancer specialists. The survey contains 11 categories to elicit the perception and identification of mental illnesses in patients, diagnostic procedure, and details of antidepressant prescribed. Logistic regression was used to explore the association of oncologists' characteristics and management of depression in breast cancer patients. Results: Survey response rate was $31.3 \%$. Ninety percent of the oncologists perceived the prevalence of depression to be less than $20 \%$, while half believed that the proportion was less than $5 \%$. The most commonly-used medication for the treatment of depression was BZDs (41.5\% [ $n=39]$ ), followed by Selective Serotonin Reuptake Inhibitors (SSRIs) (30.9\% [ $n=29]$ ). Benzodiazepines (BZDs) were most frequently prescribed (41.5\%) despite its known ineligible dependency, followed by Selective Serotonin Reuptake Inhibitors (SSRIs) (30.9\%). Choice of BZDs was significantly associated with the career length of oncologists (Odds Ratio $[\mathrm{OR}]=8.20)$, and safety of drug $(\mathrm{OR}=5.57)$. Contrarily, prescription of SSRIs was associated with efficiency of drug $(\mathrm{OR}=7.07)$. Conclusion: Relative to anxiety and insomnia, a lower awareness regarding depression was common among study oncologists. In addition, the quality of care varied among these oncologists. It is necessary to improve both the awareness and management of mental illnesses in order to enhance the total clinical care of breast cancer patients.

Palliat Care Res 2014; 9(3): 132-9
\end{abstract}

Key words: Depression, Benzodiazepine, breast cancer, SSRI, quality of medical care

\section{Introduction}

Breast cancer is the most common cancer among women in Japan, and accounted for $19.2 \%$ of all female cancer patients in $2007^{1)}$. The 5-year survival rate was $87.7 \%$, calculated based on data from regional cancer registration records from 1999 to 20032). Because breast cancer is associated with sexuality and femininity, patients experience various temporary psychological reactions (e.g., anger, feeling of guilt, fear, anxiety, and disappointment), and are also susceptible to mental illnesses ${ }^{3-7)}$. Depression can impair patient quality-of-life (QOL), compliance with treatment, and survival rate, and leads to an increased risk of suicide ${ }^{4,8,9)}$. Derogatis, et al. ${ }^{10)}$ reported that $47 \%$ of cancer patients suffered from mental illness. Of these, $68 \%$ suffered from adjustment disorder, while 13\% suffered from depression. Fann, et al. ${ }^{11)}$ reviewed the prevalence of major depression in patients with breast cancer and reported rates of $10 \backsim 25 \%$. Regarding Japanese patients, Akechi, et al. ${ }^{12)}$ investigated the prevalence of mental diseases in outpatients with breast cancer treated with surgery, and found percentages for adjustment disorder and major depression of $18 \%$ and $5 \%$, respectively. Okamura, et al. ${ }^{13)}$ reported prevalences of $35 \%$ and $7 \%$ for adjustment disorder and major depression, respectively in patients with breast cancer recurrence.

Some difficulties regarding the treatment of concomitant mental diseases have been noted by oncologists. Because mental disorders lie outside the normal scope of oncological treatment, some oncologists may underestimate the extent of such diseases and choose an inappropriate therapy ${ }^{14,15)}$. In addition, patient hesitancy to report mental problems due to prejudice against mental illnesses as well as stigma associated with receiving mental care complicates the detection of such problems ${ }^{15,16)}$. Although several recommended diagnostic crite-

Corresponding author: Izumi Sato Department of Clinical Study and Informatics, Center for Clinical Sciences, National Center for Global Health and Medicine

1-21-1, Toyama Shinjuku-ku Tokyo 162-8655 Japan

TEL 03-3202-7181 FAX 03-3202-7818 E-mail: izumisato-tky@umin.ac.jp 
ria and screening tools are available for the medical care of depres$\operatorname{sion}^{17,18)}$, the extent to which such tools are effectively utilized by oncologists is not known. One previous study reported that the rate of patient referrals for psychiatric consultation in Japan was lower than that in United States ${ }^{19}$. It has also been reported that the level of collaboration between oncologists and mental health professionals is inadequate in $\operatorname{Japan}^{20}$. However, the situation regarding collaboration between oncologists and mental health professionals in the care of breast cancer patients with depression remains unknown.

Treatment algorithms for depression have been published in the United States, Asia, and Europe ${ }^{21,22)}$. Selective Serotonin Reuptake Inhibitors (SSRIs) are recommended as first-line agents in each algorithm due to their favorable risk-benefit profiles. In the past, benzodiazepines (BZDs) served as first-line medications for treatment of depression $^{23-26)}$. However, after the discovery of several undesirable side effects (e.g., drug resistance, addiction), the usage of BZDs decreased rapidly, along with the enactment of strict regulations on the use of BZDs in many counties ${ }^{23,24}$. The Japanese algorithm also recommends SSRIs as first-line agents, and permits the co-administration of BZDs for the initial 4 weeks of treatment in cases of patient insomnia or (and) anxiety. Furthermore, Tajima ${ }^{27)}$ reported that BZDs monotherapy in place of SSRIs is still common in Japan. Because few studies have evaluated the effectiveness and safety of antidepressants for Japanese depressed breast cancer patients, the optimal medications remain unknown ${ }^{25,26}$. In addition, the current state of the clinical care of depressed breast cancer patients by oncologists also remains unknown. Accordingly, we investigated the perception of the prevalence of mental diseases in breast cancer patients and the therapeutic approach to depression undertaken by oncologists.

\section{Methods}

\section{Developing the questionnaire}

We developed a self-reported questionnaire based on the expert opinions of psychiatrists and oncologists, as well as a review of previous studies ${ }^{3-15,17,18,20-27)}$ related to mental illness among cancer patients. There were three essential questions of interest: (1) the perceptions among oncologists regarding the prevalence of mental illnesses (depression, anxiety, and sleep disorder); (2) the accompanying frequency of referral to mental health care professionals; and, (3) the applied pharmacological therapies. Each of these questions and the implemented wordings were selected by the author, and revised based on the expert opinions of psychiatrists and oncologists. The contents of the questionnaire comprised the following items (note that all of the questions were written in Japanese).

\section{Survey contents}

- Background characteristics of the oncologist (age, diagnosis and treatment department, years of experience as an oncologist, hospital name, hospital site, hospital type [university hospital, cancer hospital, general hospital, and other])

- Presence or absence of mental health professionals (psychiatrists, clinical psychologists, and liaison nurses)

- Perception regarding the prevalence of mental illnesses (depression, anxiety, and sleep disorder) among breast cancer patients (less than 5\%, 5-20\%, 20-30\%, and more than 30\%)

- Diagnostic approach for depression (Five items: based on patient condition, using a questionnaire, left to a psychiatrist's judgment, none, and other; multiple answers were permitted)

- Treatment strategy for depression (Seven items: referral to a psychiatrist [in-hospital], referral to a psychiatrist [out-of-hospital], referral to another mental health professional, referral to a patient group, medication treatment, adoption of an observational approach [without medication treatment], and other)

- Criterion for referral to a mental health professional (Four items: patient has suicidal thoughts, failure to communicate with patient, poor improvement in medication treatment, and other)

- Name of the medication used for treating depression

- Reasons for choice of medication (Nine items: abundant experience, effectiveness, safety, cost, allowed co-medication, frequency of administration, drug form, patient's preference, and other; multiple answers were permitted)

\section{Subjects}

The questionnaire was sent to 352 breast cancer specialists who had participated in one of the following clinical trials: National Surgical Adjuvant Study of Breast Cancer, Selection of Effective Chemotherapy for Breast Cancer [SELECT BC], and SELECT BC-CONFIRM. These trials were supported by the Comprehensive Support Project for Oncology Research of the Public Health Research Foundation (PHRF) in Japan. PHRF supports a variety of clinical research activities to build the foundations of advanced medicine, including epidemiological and health outcome research (e.g., QOL, economic evaluations) via the implementation of large clinical trials.

\section{Procedure}

The survey was conducted from October through November of 2009. We sent the questionnaire to the subjects, along with a letter of request for participation and a stamped, self-addressed envelope.

\section{Statistical analysis}

We summarized the backgrounds of the subjects, the perceptions of the prevalence of mental illnesses (depression, anxiety, and sleep disorder), and the first-choice medication for treatment of depression. We also abridged the diagnostic methods for depression, treatment approach, and criterion for referral to mental health professionals by the presence or absence of mental health professionals at their own hospitals. To explore the reason for the choice of a medication as a first-line agent among oncologists, logistic regression was used, with calculation of the adjusted odds ratios (ORs) and 95\% confidence intervals (CIs). SAS version 9.128) was used for all analyses.

\section{Results}

We received questionnaires from 110 of 352 contacted oncologists, yielding a response rate of $31.3 \%$. The background characteristics of the responding oncologists are shown in Table 1. Half (56.4\%) of these oncologists were in their 40 's. The mean number of years of experience as an oncologist $( \pm \mathrm{SD})$ was $17.9 \pm 6.8$ years, and the mean 
Table 1 Characteristics of the Subjects

\begin{tabular}{|c|c|}
\hline Variable & \\
\hline Experience as an Oncologist-yr & $17.9 \pm 6.8$ \\
\hline Total number of patients in charge for a month & $236.4 \pm 142.4$ \\
\hline \multicolumn{2}{|l|}{ Age group-no. (\%) } \\
\hline $30-39 \mathrm{yr}$ & $13(11.8)$ \\
\hline $40-49 \mathrm{yr}$ & $62(56.4)$ \\
\hline $50-59 \mathrm{yr}$ & $28(25.5)$ \\
\hline $60-69 \mathrm{yr}$ & $7 \quad(6.4)$ \\
\hline \multicolumn{2}{|l|}{ Type of hospital-no. (\%) } \\
\hline General hospital & $71(64.6)$ \\
\hline University hospital & $25(22.7)$ \\
\hline Cancer center & $12(10.9)$ \\
\hline Others & $2(1.8)$ \\
\hline Presence of Psychiatrist-no. (\%) & $92(85.2)$ \\
\hline Presence of Clinical Psychologist and Liaison Nurse-no. (\%) & $64(61.5)$ \\
\hline
\end{tabular}

*Plus-minus values represent means \pm SD.

Table 2 The perception of the prevalence of depression, anxiety, and sleep disorder by oncologists

$n=110$

\begin{tabular}{rccc}
\hline & Depression & Anxiety & Sleep disorder \\
\cline { 2 - 4 } & & $n(\%)$ & \\
\hline Perception of prevalence & & & $12(10.9)$ \\
$<5 \%$ & $49(44.5)$ & $41(37.3)$ & $51(46.4)$ \\
$5-20 \%$ & $50(45.5)$ & $27(24.5)$ & $30(27.3)$ \\
$20-30 \%$ & $8(7.3)$ & $30(27.3)$ & $11(10.0)$ \\
$>30 \%$ & $3(2.7)$ & & \\
\hline
\end{tabular}

total number of patients under their care $( \pm \mathrm{SD})$ was $234.8 \pm 142.8$ patients. The most common type of hospital was general hospital (64.6\%). Regarding the presence of mental health care professionals, $85.2 \%(n=92)$ and $61.5 \%(n=64)$ of oncologists reported the presence of a psychiatrist, and of a clinical psychologist and liaison nurse (including part-timers) at their hospital, respectively.

The reported perceptions of the oncologists regarding the prevalence of depression, anxiety, and sleep disorder in breast cancer patients are shown in Table 2. We categorized the reported percentages into 4 groups (less than 5\%, 5-20\%, 20-30\%, and more than 30\%). Ninety percent of the oncologists perceived the prevalence of depression to be less than $20 \%$, while half believed that the proportion was less than $5 \%$. These oncologists also perceived a low prevalence of anxiety (Spearman rho $=0.53, p<0.01)$ and sleep disorder $(0.44, p$ $<0.01)$. As for anxiety, $90 \%$ of the oncologists perceived the prevalence to be greater than $5 \%$. Of these, $27 \%$ indicated a prevalence of more than $30 \%$. Regarding sleep disorder, half of surgeons (46\%) perceived a prevalence of 5 $-20 \%$, and $27 \%$ indicated a prevalence of $20-30 \%$. Additionally, $16 \%$ of oncologists believed the prevalence to be less than $5 \%$. The perception of the prevalence of depression was less than those of anxiety and sleep disorder.

The most common diagnostic approach for depression was "based on patient condition" ( $84.3 \%[n=91])$, followed by "left to a psychiatrist's judgment" (45.4\% $[n=49])$ and "using a questionnaire" $(4.6 \%[n=5])$. Moreover, most of the oncologists relied on a psychiatrist to assess the severity of depression $(72.2 \%[n=78])$, but rarely used a questionnaire $(2.8 \%[n=3])$.

The frequency of referrals to mental health professionals, categorized by the presence or absence of mental health professionals at the oncologists' hospitals, is shown in Figure 1. Most oncologists (79\%) who belonged to a hospital with psychiatrists referred patients to these professionals more than several times per year. Of these, $12 \%$ made such referrals more than several times per month. In contrast, oncologists belonging to hospitals without psychiatrists did not make such referrals. The frequency of referrals to clinical psychologists and liaison nurses tended to be lower than to psychiatrists. Sixty-five percent of oncologists belonging to hospitals with clinical psychologists and liaison nurses referred patients to these professionals more than several times per year. The most common reason for referral to psychiatric experts was "failure to communicate with patient" (58.3\% $[n=63])$, followed by "patient has suicidal thoughts" ( $46.3 \%[n=$ $50])$ and "poor improvement in response to treatment with medication" $(40.7 \%[n=44])$.

The most commonly-used medication for the treatment of depres- 


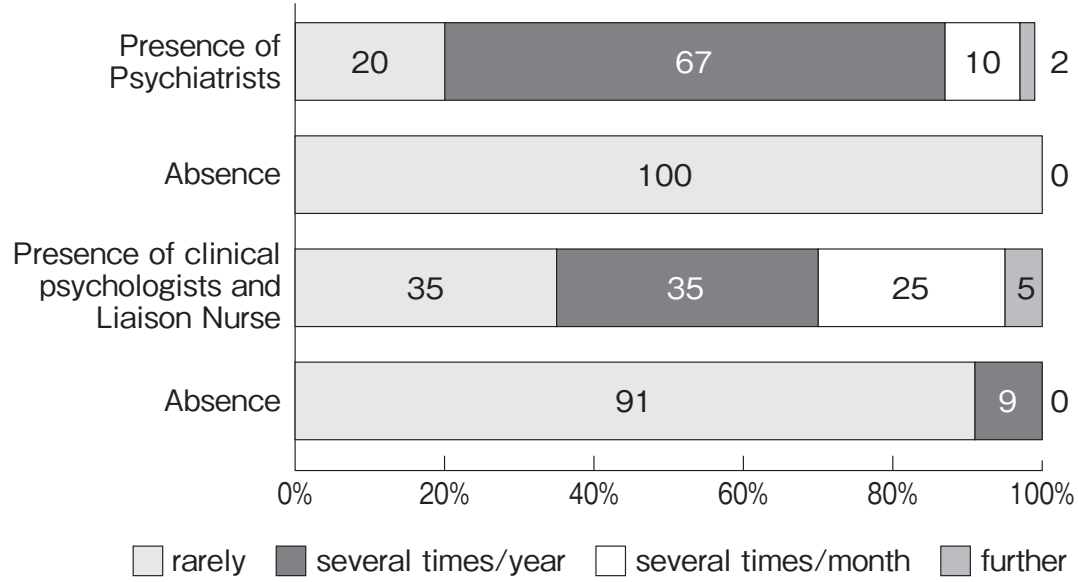

Figure 1 Frequency of referrals to mental health professionals

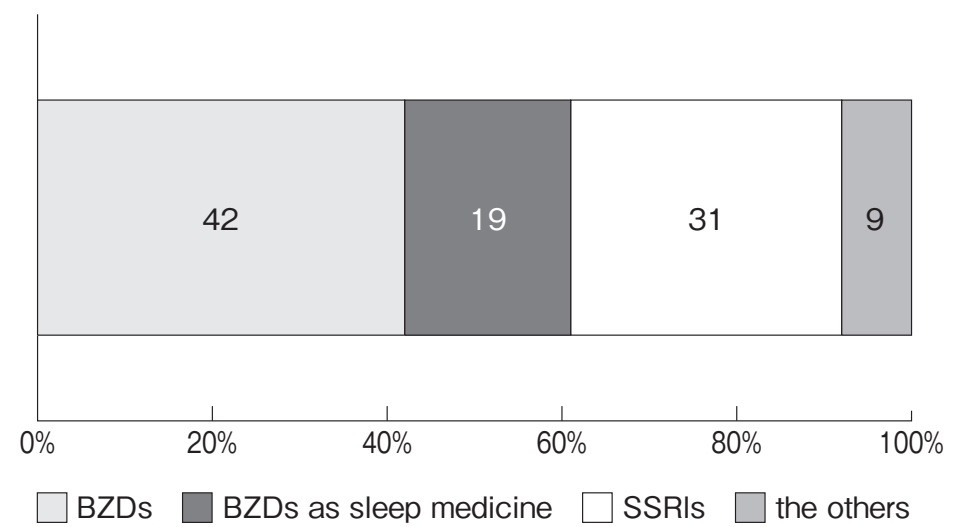

Figure 2 Type of first-line medication

sion was BZDs $(41.5 \%[n=39])$, followed by SSRIs (30.9\% $[n=$ 29]). Of these, the most frequently prescribed agents among BZDs and SSRIs were Etizolam (79.5\%) and Paroxetine (72.4\%), respectively (Figure 2).

We conducted a logistic regression analysis to determine the reason for the selection of BZDs by oncologists as the first-line medication, with "chose BZDs as first-line medication" as a dependent variable (Table 3-a). The odds ratios of "abundant experience", "safety", and "referral to psychiatrists or use of screening tools" were 8.20 (95\% confidence interval [CI]: 2.59 to 25.94 ), 5.57 (95\% CI: 1.70 to 18.32), and 0.16 ( $95 \%$ CI: 0.05 to 0.54 ), respectively. The other variables were not significantly associated with the selection of BZDs as first-line medication. A similar analysis for SSRIs was also conducted, with "chose SSRIs as first-line medication" as the dependent variable (Table 3-b). The odds ratio of "efficiency of the medicine" was 7.07 $(p=0.004)$. The other variables were not significantly associated with selection of SSRIs as the first-line medication.

\section{Discussion}

In this study, we investigated the perceptions among oncologists regarding the prevalence of mental diseases in patients with breast cancer, as well as their therapeutic approach to depression using a self-reported questionnaire. We found that most of these oncologists perceived the prevalence of depression among breast cancer patients to be less than $20 \%$. Of these, half believed it to be less than $5 \%$. In addition, the associated referral frequency was found to be influenced by the presence/absence of mental health professionals at the oncologist's hospital. The most common first-line drug was reported as BZDs, followed by SSRIs.

The prevalence of depression reported in previous studies has varied $^{10-13)}$. Our study result is similar to the prevalence of major depression in previous Japanese studies by Akechi, et al. ${ }^{12)}$ and Okamura, et al. ${ }^{13)}$, which reported prevalences among Japanese patients of $5 \%$ and $7 \%$, respectively. However, they also reported prevalences of adjustment disorder of $18 \%$ and $35 \%$, respectively. The possibility of overlooked and untreated depressive patients should be recognized. In addition, the presence of a relevant comorbidity such as anxiety and insomnia should be considered, as non-psychiatric professionals regarded the morbidity of depression to be lower than those of anxiety and sleep disorder ${ }^{29}, 30$. Moreover, patient hesitancy to report mental problems should also be considered. It can be difficult to detect symptoms or to refer patients to mental health experts, even when an oncologist has become aware that a patient requires mental care. Although screening tools, such as questionnaires are recommended for the early detection of depression ${ }^{17}$, they were rarely used by our 
Table 3 Logistic regression analysis:

a. "BZDs as the first-line medication" as the dependent variable.

\begin{tabular}{rlc}
\hline \multicolumn{1}{c}{ Variable } & Odds ratio (95\% Cl) & $P$ value \\
\hline Experience as an Oncologist (per 1-yr increase) & $0.96(0.85-1.08)$ & 0.43 \\
Total number of patients under care per month (per 1-person increase) & $1.00(1.00-1.01)$ & 0.23 \\
Age (per 10-yr increase) & $1.14(0.40-3.25)$ & 0.81 \\
Presence of clinical psychologists and Liaison Nurse (yes vs no) & $1.04(0.33-3.28)$ & 0.79 \\
Presence of Psychiatrists (yes vs no) & $1.00(0.28-3.67)$ & 0.93 \\
Referral to psychiatrists or use of screening tools (yes vs no) & $0.16(0.05-0.54)$ & 0.004 \\
Abundant experience with the medicine (yes vs no) & $8.20(2.59-25.94)$ & 0.0003 \\
Efficiency of the medicine (yes vs no) & $0.99(0.27-3.65)$ & 0.96 \\
Safety of the medicine (yes vs no) & $5.57(1.70-18.32)$ & 0.002 \\
Allowed co-medication (yes vs no) & $1.14(0.10-12.79)$ & 0.56 \\
Frequency of administration (yes vs no) & $0.97(0.03-29.42)$ & 0.64 \\
Request from patients (yes vs no) & $2.85(0.39-20.73)$ & 0.43 \\
\hline
\end{tabular}

b. "SSRIs as the first-line medication" as the dependent variable.

\begin{tabular}{rcc}
\multicolumn{1}{c}{ Variable } & Odds ratio (95\% Cl) & $P$ value \\
\hline Experience as an Oncologist (per 1-yr increase) & $0.93(0.82-1.05)$ & 0.23 \\
Total number of patients under care per month (per 1-person increase) & $1.00(0.99-1.00)$ & 0.28 \\
Age (per 10-yr increase) & $0.33(0.10-1.08)$ & 0.07 \\
Presence of clinical psychologists and Liaison Nurse (yes vs no) & $0.61(0.31-1.21)$ & 0.16 \\
Presence of Psychiatrists (yes vs no) & $2.02(0.72-5.63)$ & 0.18 \\
Referral to psychiatrists or use of screening tools (yes vs no) & $1.86(0.58-5.98)$ & 0.29 \\
Abundant experience with the medicine (yes vs no) & $1.93(0.60-6.22)$ & 0.27 \\
Efficiency of the medicine (yes vs no) & $7.07(1.90-26.39)$ & 0.004 \\
Safety of the medicine (yes vs no) & $0.45(0.12-1.62)$ & 0.22 \\
Allowed co-medication (yes vs no) & $0.72(0.07-7.59)$ & 0.78 \\
Frequency of administration (yes vs no) & $2.78(0.11-69.00)$ & 0.53 \\
Request from patients (yes vs no) & $1.43(0.13-15.72)$ & 0.77 \\
\hline
\end{tabular}

study subjects.

The results suggested that a referral collaboration between oncologists and mental health professionals has become established in hospitals with mental health experts. Most such oncologists reported a referral frequency of several times per year. It appears that oncologists do not have substantial opportunities for referral. This may be a natural consequence of the belief by half of these professionals that the morbidity of depression is less than $5 \%$. However, possible explanations include undiagnosed cases of depression, as well as patient hesitancy to report mental problems, as mentioned above. Previous studies have reported its prevalence among limited study populations (e.g., patients with recurrent cancer, outpatient surgery). However, the prevalence among general breast cancer patients remains unknown. Further studies to investigate the morbidity of depression among all breast cancer patients are required. In addition, cooperation between oncologists and mental health professionals is also necessary to properly manage patients with potential mental problems. Furthermore, not all hospitals have mental care experts, especially clinical psychologists and liaison nurses, and oncologists may be reluctant to re- fer patients to other hospitals or clinics. Various methods to promote cooperation with experts at other hospitals should be considered for hospitals lacking in mental health professionals.

Our findings suggest that BZDs are still more popular than SSRIs in Japan. In contrast, in the United States and Europe, SSRIs have become the mainstream pharmacological therapy for depres$\operatorname{sion}^{23)}$. The prescribed dosages of BZDs have also decreased due to the risk of dependency and addiction ${ }^{23}$. In our study, BZDs were chosen based on stated reasons of abundant experience and safety. This finding suggests that oncologists are familiar with BZDs and recognized them as safe medicines. However, the adverse effects of Etizolam, such as dependency might have not been recognized, as it has been marketed only in Japan, Korea, and Italy ${ }^{31)}$. Moreover, the Japanese treatment algorithm for depression recommends SSRIs as first-line agents rather than BZDs. Although the possibility exists of insufficient awareness regarding drug treatment strategies for depression, since $30 \%$ of oncologists choose SSRIs as the first-line agent, it appears that SSRIs are also becoming common in the treatment of depressive breast cancer patients by oncologists. A caution regarding 
the co-administration of SSRIs with tamoxifen has been issued in the clinical practice guidelines for breast cancer from the National Comprehensive Cancer Network, as the co-administration of SSRIs with tamoxifen may decrease the plasma concentration of tamoxifen's active metabolite, which may impact its efficacy ${ }^{32,33)}$. In our study, we did not inquire regarding the impact of tamoxifen on drug treatment for depression. Further research studies are needed to validate the risks and benefits of taking SSRIs with tamoxifen in Japan.

This study has several limitations. The response rate was low, which might have led to misleading results due to a response bias. In addition, it is possible that the study data was of inadequate accuracy, as our findings were based on subjective answers. Accordingly, further studies are required using objective data to investigate the prevalence of depression and prescribing trends in depression. Despite these limitations, our findings should contribute to an understanding of the current state of medical care for depressive breast cancer patients by oncologists.

\section{Conclusion}

Relative to anxiety and insomnia, a lower awareness regarding depression was common among study oncologists. In addition, the quality of care varied among these oncologists. It is necessary to improve both the awareness and management of mental illnesses in order to enhance the total clinical care of breast cancer patients.

Acknowledgments The authors wish to thank Yutaka Matsuyama, Ayano Takeuchi, Satoshi Iimuro, Yukari Uemura for useful comments regarding this study. The authors also wish to thank the oncologists who were members of the Public Health Research Foundation as well as the Secretariats of the Health Outcomes Research (CSP-HOR) of the Public Health Research Foundation.

\section{REFERENCES}

1) Matsuda $T$, Marugame $T$, Kamo K, et al. Cancer incidence and incidence rates in Japan in 2006: based on data from 15 population-based cancer registries in the monitoring of cancer incidence in Japan (MCIJ) project. Jpn J Clin Oncol 2012; 42(2): 139-47. PubMed PMID: 22172347. Epub 2011/12/17. eng.

2) Matsuda T, Ajiki W, Marugame T, et al. Research Group of Population-Based Cancer Registries of Japan. Population-based survival of cancer patients diagnosed between 1993 and 1999 in Japan: a chronological and international comparative study. Jpn J Clin Oncol 2011; 41(1): 40-51.

3) Schover LR. The impact of breast cancer on sexuality, body image, and intimate relationships. CA Cancer J Clin 1991; 41(2): 112-20.

4) Knobf MT. Psychosocial responses in breast cancer survivors. Semin Oncol Nurs 2007; 23(1):71-83. PubMed PMID: 17303518.

5) Maguire P. ABC of breast diseases. Psychological aspects. BMJ 1994; 309(6969): 1649-52.

6) Meyerowitz BE. Psychosocial correlates of breast cancer and its treatments. Psychol Bull 1980; 87(1): 108-31.
7) Oktay J. Psychosocial aspects of breast cancer. Lippincotts Prim Care Pract 1998; 2(2): 149-59.

8) Watson M, Haviland JS, Greer S, et al. Influence of psychological response on survival in breast cancer: a population-based cohort study. Lancet 1999; 354(9187): 1331-6.

9) Hjerl K, Andersen EW, Keiding N, et al. Depression as a prognostic factor for breast cancer mortality. Psychosomatics 2003; 44(1): 24-30.

10) Derogatis LR, Morrow GR, Fetting J, et al. The prevalence of psychiatric disorders among cancer patients. JAMA 1983; 249(6): 751-7.

11) Fann JR, Thomas-Rich AM, Katon WJ, et al. Major depression after breast cancer: a review of epidemiology and treatment. Gen Hosp Psychiatry 2008; 30(2): 112-26. PubMed PMID: 18291293.

12) Akechi T, Okuyama $T$, Imoto $S$, et al. Biomedical and psychosocial determinants of psychiatric morbidity among postoperative ambulatory breast cancer patients. Breast Cancer Res Treat 2001; 65(3): 195-202.

13) Okamura H, Watanabe T, Narabayashi $M$, et al. Psychological distress following first recurrence of disease in patients with breast cancer: prevalence and risk factors. Breast Cancer Res Treat 2000; 61(2): 131-7.

14) Furukawa TA, Kitamura T, Takahashi K. Treatment received by depressed patients in Japan and its determinants: naturalistic observation from a multi-center collaborative follow-up study. J Affect Disord 2000; 60(3): 173-9.

15) Hirschfeld R, Keller MB, Panico S, et al. The National Depressive and Manic-Depressive Association consensus statement on the undertreatment of depression. JAMA 1997; 277: 333-40.

16) Hirosawa M, Shimada H, Fumimoto H, et al. Response of Japanese patients to the change of department name for the psychiatric outpatient clinic in a university hospital. Gen Hosp Psychiatry $2002 ; 24(4): 269-74$.

17) U.S. Preventive Services Task Force. Screening for depression in adults: US Preventive Services Task Force recommendation statement. Ann Intern Med 2009; 151(11): 784-92.

18) Akizuki N, Yamawaki S, Akechi T, et al. Development of an Impact Thermometer for use in combination with the Distress Thermometer as a brief screening tool for adjustment disorders and/or major depression in cancer patients. J Pain Symptom Manage 2005; 29(1): 91-9.

19) Kishi Y, Meller WH, Kato M, et al. A Comparison of Psychiatric Consultation-Liaison Services Between Hospitals in the United States and Japan. Psychosomatics 2007; 48(6): 517-22.

20) Sasa M, Sumitomo I, Nishimura R. [Team management for patients with breast cancer]. Nihon Rinsho 2007; 65(Suppl 6): 589-92. PubMed PMID: 17679214. Epub 2007/08/08. jpn.

21) American Psychiatric Association (APA). Practice guideline for the treatment of patients with major depressive disorder, third edition. American Psychiatric Association (APA), Arlington (VA), 2010; 152 .

22) National Collaborating Centre for Mental Health. Depression: The Treatment and Management of Depression in Adults (Up- 
dated Edition). Leicester UK: The British Psychological Society \& The Royal College of Psychiatrists, 2010.; 2010.

23) Stafford RS, MacDonald EA, Finkelstein SN. National patterns of medication treatment for depression, 1987 to 2001. Prim Care Companion J Clin Psychiatry 2001; 3(6): 232.

24) Fraser AD. Use and abuse of the benzodiazepines. Ther Drug Monit 1998; 20(5): 481-9.

25) Furukawa T, Streiner D, Young L. Antidepressant plus benzodiazepine for major depression. Cochrane database Syst Rev (Online). 2001 (2): CD001026.

26) Tsutsui S, Okuse T, Sasaki D, et al. Clinical evaluation of paroxetine hydrochloride and Trazodone hydrochloride for depression: double-blinded comparative study. Japanese Pharmacology \& Therapeutics 2000;28(Suppl.1): 161-85.jpn.

27) Tajima O. Reconsideration of prescription of Benzodiazepine. Japanese Journal of clinical Psychopharmacology 2001; 30: 1065-9. jpn.

28) SAS S, Guide SUs. Version 9.1. SAS Institute Inc, Cary, NC. 2003.
29) Hardman A, Maguire P, Crowther D. The recognition of psychiatric morbidity on a medical oncology ward. J Psychosom Res 1989; 33(2): 235-9.

30) Fiorentino L, Ancoli-Israel S. Insomnia and its treatment in women with breast cancer. Sleep medicine reviews 2006; 10(6): 419-29.

31) Mitsubishi Tanabe Pharma Corporation. interview form of DEPAS tablets and fine granules 1\%. 2012.

32) Jin Y, Desta Z, Stearns V, et al. CYP2D6 genotype, antidepressant use, and tamoxifen metabolism during adjuvant breast cancer treatment. J Natl Cancer Inst 2005; 97(1): 30-9.

33) NCCN. NCCN Clinical Practice Guidelines in Oncology (NCCN Guidelines): Breast Cancer, Version3. Available from: http:// www.nccn.org/professionals/physician_gls/f_guidelines.asp

Potential conflicts of interest; The authors indicated no potential conflicts interest. 


\title{
原蓶
}

\section{乳がん専門医による乳がん患者に対する うつ病診療の実態調査}

\author{
佐藤 泉美 ${ }^{1,2)}$, 牧野 春彦, 3), \\ 下妻晃二郎 ${ }^{2,4)}$, 大橋 靖雄, ${ }^{1,2}$
}

\author{
1) 東京大学大学院 医学系研究科 健康科学・看護学専攻 疫学・予防保健学分野, \\ 2) パブリックヘルスリサーチセンター, \\ 3) 新潟市民病院 乳腺外科, \\ 4) 立命館大学生命科学部 生命医学学科
}

【目的】乳がん専門医によるうつ病診療の実態調査【方法】乳がん専門医 352 名に, うつ病診療状況に関する調査票を郵 送した.【結果】110 名 (31.3\%) から回答を得た. 乳がん患者のうつ病罹患割合は, $90 \%$ の医師が $20 \%$ 以下, 約半数が $5 \%$ 以下と回答した. 第一選択薬はベンゾジアゼピン系抗不安薬 (BZD) が最多で (41.5\%), 次が選択的セロトニン再取り込み阻 害薬 (SSRI) だった (30.9\%). BZD 使用の医師は, 使用経験の豊富さ (オッズ比 [OR] 8.20), 安全性 (OR 6.27) で選んでおり, SSRI は, 効果の高さ (OR 7.07) で選ばれていた.【結論】乳がん専門医の乳がん患者のうつ病診療では, 調査票に基づく診 断や薬物療法等において高い水準の医療が均しく行われているとは言い難く, 精神科系専門家との連携も含め, 診療環境整 備の必要性が示唆された.

Palliat Care Res 2014; 9(3): 132-9

Key words: うつ病, ベンゾジアゼピン系抗不安薬, 乳がん, 選択的セロトニン再取り込み阻害薬, 診療の質 